\title{
The OECD Principles of Corporate Governance*
}

\section{Introduction}

$\mathrm{T}$ The integrity of businesses and markets is central to the vitality and stability of our economies. So good corporate governance - the rules and practices that govern the relationship between the managers and shareholders of corporations, as well as stakeholders like employees and creditors - contributes to growth and financial stability by underpinning market confidence, financial market integrity and economic efficiency. Recent corporate scandals have focussed the minds of governments, regulators, companies, investors and the general public on weaknesses in corporate governance systems and the need to address this issue.

The OECD Principles of Corporate Governance provide specific guidance for policymakers, regulators and market participants in improving the legal, institutional and regulatory framework that underpins corporate governance, with a focus on publicly traded companies. They also provide practical suggestions for stock exchanges, investors, corporations and other parties that have a role in the process of developing good corporate governance. They have been endorsed as one of the Financial Stability Forum's 12 key standards essential for financial stability.

The OECD Principles were originally issued in 1999 and have since become the international benchmark for corporate governance, forming the basis for a number of reform initiatives, both by governments and the private sector. The Principles were revised in 2003 to take into account developments since 1999, through a process of extensive and open consultations, and drawing on the work of the Regional Corporate Governance Roundtables for non-OECD countries. The new

* Originally published by the OECD in English and French under the titles:

Policy Brief: The OECD Principles of Corporate Governance, C OECD 2004. All rights reserved.

Synthèses: Les principes de gouvernement d'entreprise à l'OCDE, C OECD 2004. All rights reserved. 
Principles were agreed by OECD governments in April 2004. This Policy Brief outlines the salient features of the Principles and illustrates how they address key corporate governance issues.

\section{What are the Principles and what issues do they address?}

The Principles cover six key areas of corporate governance - ensuring the basis for an effective corporate governance framework; the rights of shareholders; the equitable treatment of shareholders; the role of stakeholders in corporate governance; disclosure and transparency; and the responsibilities of the board (see Box 1). There are explanatory annotations for each area that also indicate the range of policy measures which have proved useful in achieving them. Key to the success of the Principles is that they are principles-based and nonprescriptive so that they retain their relevance in varying legal, economic and social contexts. 


\section{Box 1. The main areas of the OECD Principles}

I. Ensuring the basis for an effective corporate governance framework The corporate governance framework should promote transparent and efficient markets, be consistent with the rule of law and clearly articulate the division of responsibilities among different supervisory, regulatory and enforcement authorities.

II. The rights of shareholders and key ownership functions

The corporate governance framework should protect and facilitate the exercise of shareholders' rights.

III. The equitable treatment of shareholders

The corporate governance framework should ensure the equitable treatment of all shareholders, including minority and foreign shareholders. All shareholders should have the opportunity to obtain effective redress for violation of their rights.

IV. The role of stakeholders in corporate governance

The corporate governance framework should recognise the rights of stakeholders established by law or through mutual agreements and encourage active cooperation between corporations and stakeholders in creating wealth, jobs, and the sustainability of financially sound enterprises.

V. Disclosure and transparency

The corporate governance framework should ensure that timely and accurate disclosure is made on all material matters regarding the corporation, including the financial situation, performance, ownership, and governance of the company.

VI. The responsibilities of the board

The corporate governance framework should ensure the strategic guidance of the company, the effective monitoring of management by the board, and the board's accountability to the company and the shareholders. 
The basic requirements of the institutional and legal/regulatory framework needed to support effective corporate governance are an integral part of the Principles. The text includes principles for developing such a framework and addresses the need for laws and regulations which are both enforceable and are backed by effective enforcement agencies. Experience around the world shows that although the powerful concept of a listed company has been successfully introduced in many countries, the accompanying legal and regulatory system has often lagged, leading in some cases to abuse of minority shareholders and to reduced growth prospects when financial markets lose credibility - or fail to achieve it in the first place.

Other areas covered by the Principles are aimed at establishing an effective system of checks and balances between boards and management. Professional managers, for example, have a key role to play in the modern listed or widely-held company, but to avoid possible misuse of their position requires, inter alia, effective monitoring by the board. The Principles stress that such monitoring should not involve day-today management but rather ensure strategic guidance of the company and the oversight of internal controls.

But who monitors the monitors? The board in turn is accountable to shareholders who, the Principles maintain, should be able to exercise their fundamental ownership rights, including appointing and removing board members, and should be treated equitably by the company. Effective use of ownership rights to monitor and influence the board requires basic standards of disclosure and transparency, another area which is considered. Reality is, however, often more complex with companies and their management controlled by a dominant shareholder - a somewhat different case for monitoring, but one that is also covered by the Principles. Finally, if the enterprise is to be successful, the board will also have to consider stakeholders such as employees and creditors who supply the firm with resources and who also need access to timely and relevant information. Attention to stakeholders is a unique feature of the Principles.

The OECD Principles are highly relevant to a number of recent high-profile cases of corporate failure. For example, in a number of cases, boards appear to have been dormant or even to have become a part of management, rather than an active monitor of its performance. In other cases, boards appear to act simply as rubber stamps, responding to the wishes of a dominant shareholder. Shareholders appear to have been either passive or ineffective at sanctioning the board and in a number 
of cases controlling shareholders have pursued their interests at the expense of minority shareholders. Complex financial institutions and complex corporate structures around the world have also thrown into stark relief the question of conflicts of interest, which have been most apparent in some brokerage research and in fund management. The Principles have always addressed these issues, but the revised version gives them more emphasis.

\section{How to strengthen the ownership role of shareholders?}

The significant increase in the shareholdings of institutional investors in many countries in recent years is often thought to have led to the formation of a large and powerful constituency in favour of monitoring companies. In fact, institutional investors, especially those acting in a fiduciary role such as collective investment schemes and pension funds, continue to play a limited role in corporate governance as owners of companies. The central policy issue is not necessarily whether they should have additional rights as shareholders, but rather that they do not make informed use of rights they already have. This is of course to the detriment of the investor who has entrusted funds to these institutions. The general approach taken by the Principles is that the decision to exercise voting rights in an informed manner is related to both the costs and benefits of voting, so in many instances it is the incentive to vote which needs to be improved, in part through policy initiatives. The Principles do not oblige institutional investors acting in a fiduciary capacity to vote their shares, but they do call on them to disclose their voting policies. When these policies include active use of ownership rights, the Principles also recommend that institutional investors disclose how they implement these policies, including the resources they set aside for this purpose. The Principles also call for impediments to cross-border voting to be eliminated and for companies to avoid making it unduly difficult or expensive to vote.

With respect to exercising ownership rights, the Principles advocate that shareholders should have the right to remove board members and to participate in nominating them. Shareholders should be able to ask questions of the board at the general meeting and to place items on the agenda. The Principles call for the board to formulate and disclose a remuneration policy for board members and key executives, highlighting the link between remuneration and performance. Shareholders should be able to make their views known about this policy and any equity component, such as share options, should be subject to their approval. 
Even for institutional investors, the informed use of ownership rights is costly. In many instances, institutional investors feel that their stakes in individual companies are not large enough to justify these costs. To overcome this situation, the Principles recommend that the authorities allow or even encourage institutions (and other shareholders) to co-operate and coordinate their actions. However, there is an important caveat that such co-operation is not aimed at manipulating the market or obtaining control of the company without going through accepted takeover procedures. Better co-ordination in nominating and electing board members, placing proposals on the agenda and holding discussions directly with a company are all welcome as valid methods of improving corporate governance. Overall, the Principles take the view that the costs of effective ownership can and should be reduced.

As part of its approach to participation by institutional investors, the Principles call on countries to lift unnecessary regulatory barriers to a continuing dialogue between investors and companies. At the same time, recognising that such close relations can degenerate into abuses, particularly in situations where there are inherent conflicts of interest, the Principles recommend that general disclosure of information to the market should remain the practice. Any additional information released by a company to institutional investors should be aimed at helping them understand the background to such published information.

\section{How do the Principles deal with conflicts of interest?}

One of the most striking lessons of recent years is that conflicts of interest are widespread and can often lead to behaviour detrimental to shareholders, investors and stakeholders. Since conflicts of interest take many different forms they are dealt with in several different sections of the Principles. As a general approach, the Principles advocate both full disclosure and an explanation by the parties involved as to how the conflict of interest is being managed.

Managing conflicts of interest is particularly important with respect to external auditors, whose independence is crucial for financial market integrity. The Principles support the Principles of Auditor Oversight issued by the International Organisation of Securities Commissions (IOSCO) in 2002. These recommend creating a body, acting in the public interest, to provide oversight of the quality and implementation of audits. The OECD Principles recognise the importance of recent provisions 
introduced by many countries to deal with the skewed incentive structure that arises when the external auditor provides non-audit services or when he might be involved in auditing his own work. Managing the relationship with the external auditor so as to ensure a high-quality independent audit is also identified by the Principles as a key duty of the board.

An effective corporate governance framework needs to be backed by effective ways to ensure the integrity of those such as financial analysts, brokers and rating agencies that provide information or advice which could influence investors' decisions. This is necessary since close relationships between service providers and their client companies introduce the potential for conflict of interests.

It is important for the market to know whether the company is run with due regard to the interests of all its investors. To this end, the Principles state that it is essential for the company to fully disclose any material related-party transactions. Such transactions are typically between the company and entities in which it or its management have an interest, or with significant shareholders, including their close relatives and associates. The Principles call for the beneficiary of such a transaction to be obliged to inform the board, which in turn should make a disclosure to the market. This should not, however, absolve the firm from maintaining its own monitoring.

The Principles emphasise the need to protect minority shareholders, most notably where there are controlling shareholders whose interests might diverge from those of the others. This is particularly a source of concern in jurisdictions where the legal and regulatory framework for minority protection is weak. The Principles reaffirm that it is reasonable for investors to expect that the abuse of insider power, including by controlling shareholders, will be prohibited. In cases where such abuses are not specifically forbidden by legislation or where enforcement is not effective, the Principles call on policymakers to consider measures to fill such gaps.

\section{How do the Principles help strengthen company oversight by boards?}

The company board serves as the fulcrum that balances the ownership rights enjoyed by shareholders with the discretion granted to managers. Good corporate governance requires that the board, whatever its structure, focus on long-term issues, such as assessing corporate strategy, and activities that might involve a 
change in the nature and direction of the company, rather than taking on day-today operational responsibilities. However, boards as a whole and their individual members must have clearly-defined incentives and duties to ensure that the board effectively exercises its functions.

The Principles specify clearly-defined responsibilities for the board that include establishing a code of corporate ethics, ensuring compliance with laws and standards, and oversight of internal control systems for financial reporting. The board should also be responsible for formulating and disclosing a remuneration policy that highlights the link between remuneration and performance for key executives and board members. Many countries now regard as best practice the creation of a remuneration committee with independent directors.

Since the board and its members have a fiduciary duty to the company and all its shareholders, the Principles embrace a general notion of board independence and objectivity, rather than referring simply to independence from management. When a company is part of a group, the board's duty is to the company, not the group. Boards should review related party transactions using independent board members and provide confidential access for whistle-blowers who may be in a position to identify unethical conduct and abusive transactions. Although board committees for tasks such as audit, remuneration and nomination have spread in the past few years, the underlying concepts are not always well understood and committees often serve quite different roles in different companies. To avoid confusion and to inform investors, the Principles advocate that the composition, mandate and remit of committees be clearly defined and fully disclosed.

\section{How can governments use the Principles?}

Although a number of features advocated by the Principles require action by boards, investors and others, there is also an important role for governments to play. For example, boards will usually be able to adopt a structure consistent with effective supervision of management and effective accountability to shareholders. However, desirable features such as cooperation between investors and protection of minority shareholders may depend to a great extent on government action to remove regulatory barriers and to enforce rights. In addition, private actions alone might not lead to desirable corporate governance practices. Where management is entrenched and capital markets are weak, 
for example, boards may continue to avoid their responsibilities unless the authorities take remedial action.

The Principles offer broad guidance for governments to follow when reviewing whether their corporate governance framework is compatible with establishing the corporate governance they want. Policymakers are encouraged to develop the governance framework with a view to its impact on overall economic performance, market integrity and the incentives it creates for market participants and the promotion of transparent and efficient markets. This should help reduce the risk of costly over-regulation and minimise the unintended consequences of policy measures. To underpin market integrity, the legal and regulatory requirements that affect corporate governance practices should be consistent with the rule of law, transparent and enforceable.

The Principles also cover the types of mechanisms that should be established for parties to protect their rights. Supervisory, regulatory and enforcement authorities should have the authority, integrity and resources to fulfil their duties in a professional and objective manner. However, where institutional resources are constrained, the legal and regulatory requirements could be adjusted. For example, where courts are weak more reliance might have to be placed on other mechanisms to protect shareholder rights such as low shareholding thresholds for calling meetings and proposing board members or high voting thresholds for major decisions. Rulings should be timely, transparent and fully explained. Box 2 discusses in detail how the OECD helps governments to improve corporate governance. 


\section{Box 2. OECD activities to improve corporate governance}

Through its Steering Group on Corporate Governance and the Regional Corporate Governance Roundtables, the OECD serves as the international nexus for policy discussions in corporate governance. The Principles are the centrepiece of the numerous activities undertaken by the OECD to improve corporate governance. In co-operation with the World Bank, the OECD Regional Roundtables have used the Principles as a framework for policy dialogue to promote regional corporate governance reforms in Asia, Latin America, Eurasia, Southeast Europe and Russia. This activity has resulted in regional White Papers, which develop common policy objectives and highlight recommendations for policy action. The knowledge gained from the Roundtables has been made available to the public and is summarised in a recent OECD report, Experiences from the Regional Corporate Governance Roundtables, which compares the corporate governance problems faced by widely different emerging market and developing economies and elaborates on the priorities which these regions have established. This experience was in turn influential in the review of the Principles.

Good corporate governance is also necessary for state-owned companies. The ownership function of the state in companies where it is a shareholder has yet to be fully resolved, even after taking into account the beneficial effects of partial privatisation, which in many countries has opened the way to unprecedented restructuring initiatives and increased exposure to competition from private entities. The OECD Working Group on Privatisation and Corporate Governance of State-Owned Enterprises is developing a set of Guidelines that, once completed in 2005, should allow countries to better benchmark the ownership functions of the state. This work is subject to an open consultation process.

Regulatory reform is often associated with changes in the corporate governance framework. The OECD's response to the growing demand for up-to-date, comprehensive and comparable information about recent regulatory developments has been to develop the Company Law and Corporate Governance Database, a unique interactive tool for the dissemination of corporate governance legal and regulatory information. Presently available to only OECD governments, it will be made accessible to the general public via the Internet before the end of 2004 . 


\section{How was the review of the Principles carried out?}

OECD Ministers in 2002 called for an assessment of the OECD Principles by 2004, a year earlier than previously intended, in the wake of a series of corporate scandals that had undermined confidence in the integrity of corporations, financial institutions and markets. To support this work, the Ministers requested a survey of corporate governance developments in OECD countries with a view to identifying lessons to be learned and possible implications for the Principles.

The assessment was carried out under the responsibility of the OECD Steering Group on Corporate Governance with the active participation of observers from key international institutions, notably the Bank for International Settlement, International Monetary Fund, World Bank, Financial Stability Forum, International Organisation of Securities Commissions and the Basel Committee. Leading business and labour representatives, notably the Business and Industry Advisory Committee to the OECD and the Trade UnionAdvisory Committee to the OECD also participated in the Steering Group's meetings on an ad hoc basis.

The Steering Group sent a questionnaire to member countries requesting information about corporate governance issues, the forces at work and proposed policy measures. The responses, together with a review of practices in OECD member countries formed the basis of a report entitled Corporate Governance: A Survey of Developments in OECD Countries and informed the discussions of the Steering Group.

In undertaking its review, the Steering Group organised comprehensive and transparent consultations. The assessment process included extensive consultations with the private sector, labour and civil society at large. Three major consultative meetings with broad participation were held in conjunction with the Steering Group meetings. In addition, the OECD Secretary General convened two informal roundtable meetings with senior representatives from key international organisations, business and labour.

Consultations with non-member partners were first undertaken through meetings of the five Regional Corporate Governance Roundtables. Additional input was obtained from a special meeting attended by 43 non-member countries organised in co-operation with the Global Corporate Governance Forum. 


\section{What happens next?}

The Principles should be considered a living document. It is an OECD priority to make sure that they are widely disseminated and actively used. This will include a continuing policy-dialogue where policymakers, regulators and standard-setters will be able to exchange practical experience of implementing the Principles. The OECD will also continue to monitor developments and identify new trends and challenges that deserve attention. As an important part of future work, the OECD will host an international multi-stakeholder dialogue on corporate governance. This dialogue among corporations, investors, service providers, labour and others will be as inclusive as possible and provide an important opportunity to ensure that the Principles remain relevant and are actively used in the private sector. Beyond the Principles, once the Guidelines for Corporate Governance of State-Owned Enterprises are agreed they will also become an aspect of the dialogue.

As for non-OECD countries, the next stage of the Regional Roundtable process is already underway. In the case of the Russian Roundtable, the participants have agreed to create two ad hoc Task Forces to examine policy options in two priority areas: the transition towards internationally recognised financial reporting standards, and problems arising from related-party transactions, transparency of beneficial ownership and control. The Asian, Latin American and Southeast Europe Roundtables will also focus on implementation and enforcement of White Paper recommendations. The Eurasian Roundtable will shortly issue a Comparative Overview of corporate governance in the region, containing priorities for further action to be pursued in the follow-up phase. In January 2004 a draft of the revised Principles was posted on the Internet for comments from the general public. Some 75 submissions were received from private individuals, professional associations, business and trade unions and, where permission was given, they were posted on the OECD website for public access. $\mathrm{g}$ : 